\title{
ĐỀ XUẤT GIẢI PHÁP GIẢM NGẬP LỤT CHO KHU VỰC PHONG NHA - KẺ BÀNG BẰNG KÊNH ĐÀO NỐI SÔNG SON VÀ SÔNG LÝ HÒA
}

\author{
Lê Văn Nghị ${ }^{1}$
}

Tóm tắt: Vươn Quốc gia Phong Nha - Kẻ Bàng (PNKB), tỉnh Quảng Bình hai lần được công nhận là di sản thiên nhiên thế giới. Đây là điểm du lịch nổi tiếng được quy hoạch phát triển thành khu đô thị nhung thường xuyên bị ngập lụt bởi lũ tù sông Son. Sông Son có hwớng chảy gần song song với bờ biển nhưng lại bị ngăn cách với biển Đông bởi lưu vực sông Lý Hòa, tại vị trí cách cầu Lý Hòa nhỏ nhất là $15 \mathrm{~km}$, cách cửa biển Lý Hòa là $18 \mathrm{~km}$. Bài báo này trình bày giải pháp giảm lũ cho khu vực PNKB bằng cách phân lũ ngang thông qua việc mở kênh nối sông Son và sông Lý Hòa. Kênh dài $14,70 \mathrm{~km}$, có chiều rộng đáy $100 \mathrm{~m}$, độ dốc đáy $i=7 \times 10^{-5}$, cao độ đáy tại cuối kênh là $-2,0 m$. Song song vói đó là nạo vét và lên đê sông Lý Hòa. Giải pháp đã làm giảm mục nước tại khu vục PNKB tù̀ 0,5 $\div 1,5 \mathrm{~m}$, giảm diện tích ngập lut 25\%, giảm thời gian ngập lut $40 \%$ so với hiện trạng, do các trận lũ lịch sử gần đây.

Từ khóa: Phong Nha - Kẻ Bàng, Giảm lũ, Sông Gianh, Phân lũ ngang.

Ban Biên tập nhận bài: 20/02/2019 Ngày phản biện xong: 15/03/2019 Ngày đăng bài: 25/04/2019

\section{Giới thiệu chung}

Vườn Quốc gia Phong Nha - Kẻ Bàng (PNKB) thuộc địa phận huyện Bố Trạch và Minh Hóa, tỉnh Quảng Bình, cách thành phố Đồng Hới khoảng $50 \mathrm{~km}$ về phía Tây Bắc, có diện tích 1233,26km². Vườn Quốc gia được thiết lập để bảo vệ một trong hai vùng karst lớn nhất thế giới, nằm ở phần thượng lưu của sông Son. PNKB được UNESCO công nhận là di sản thiên nhiên thế giới lần 1 theo tiêu chí địa chất, địa mạo năm 2003 và lần 2 với tiêu chí đa dạng sinh học, sinh thái năm 2015 [4, 5].

Sông Son (sông Troóc) là chi lưu lớn nhất ở phía hữu của sông Gianh được bắt nguồn từ độ cao $1.350 \mathrm{~m}$ thuộc vùng núi đá vôi Kẻ Bàng Phong Nha gồm rất nhiều suối ngầm. Dòng chính sông Son chảy theo hướng Tây Nam Đông Bắc, chiều dài dòng chính $84 \mathrm{~km}$ có hệ số uốn khúc 1,79 , sông chảy qua vùng đồi đất của huyện Bố Trạch và đổ vào sông Gianh ở Vạn

IViện Khoa học Thủy lợi Việt Nam

Email:levannghi@gmail.com
Phú thuộc địa phận xã Quảng Văn huyện Quảng Trạch. Lưu vực sông Son có diện tích $1.556 \mathrm{~km}^{2}$ trong đó phần đá vôi là $723 \mathrm{~km}^{2}$ chiếm $46,5 \%$ (đã trừ lưu vực sông Rào Nan), có chiều dài $65 \mathrm{~km}$ và chiều rộng bình quân $36,8 \mathrm{~km}$, độ dốc bình quân $22,4 \%$, lưu vực có mật độ lưới sông $1,10 \mathrm{~km} / \mathrm{km}^{2}$ $[3,6]$.

Đoạn hạ lưu sông Son, vùng chảy qua địa bàn xã Cự Nẫm, Liên Trạch có lòng dẫn khúc khuỷu, nhiều đoạn cong, có nhiều mặt cắt co hẹp lớn tạo các tổn thất cục bộ trên dòng chính. Địa hình có nhiều đỉnh núi cao chạy sát mép sông, chia cắt vùng ngập lũ. Địa hình đáy sông không bằng phẳng, có nhiều đoạn cao độ đáy lớn, xen kẽ các khu vực co thắt đáy sông được đào sâu [3].

Sông Lý Hòa (sông Bố Trạch) là một sông nhỏ nằm ở phía Nam lưu vực sông Gianh, phía Đông sông Son, nằm gọn trong địa phận huyện Bố Trạch có chiều dài dòng chính $22 \mathrm{~km}$. Lòng dẫn sông từ đường $1 \mathrm{~A}$ lên thượng nguồn hẹp và sâu nhưng bờ sông lại thoải và khá ổn định, đoạn từ đường $1 \mathrm{~A}$ ra đến cửa biển mặt cắt lòng dẫn 
được mở rộng và chịu ảnh hưởng mạnh của thủy triều. Sông được bắt nguồn từ dãy núi thấp có cao độ khoảng $300 \mathrm{~m}$ nằm theo hướng Bắc Nam, nằm ở phía Đông của lưu vực sông Son. Lưu vực sông Lý Hòa có diện $177 \mathrm{~km}^{2}$ trong đó $46,7 \%$ là vùng đồi núi, đồng bằng và vùng cát ven biển có cao độ biến đổi từ $4 \div 10 \mathrm{~m}$ chiếm $53,3 \%$ diện tích lưu vực. Phần mép sông có cao độ $1,0 \div 1,5 \mathrm{~m}$, gần cửa sông là vùng đất trũng ướt bị thủy triều làm ngập thường xuyên [6] (Hình 1, Hình 3).

Đường phân thủy giữa lưu vực sông Son và sông Lý Hòa có cao độ thấp nhất từ $8 \div 10 \mathrm{~m}$. Khoảng cách từ sông Son sang sông Lý Hòa là $14.740 \mathrm{~m}$, địa hình có cao độ từ $2 \div 5 \mathrm{~m}$. Với các trận lũ hàng năm, người dân địa phương ghi nhận được mực nước chênh lệch giữa hai lưu vực qua điểm phân thủy lên đến vài ba mét.

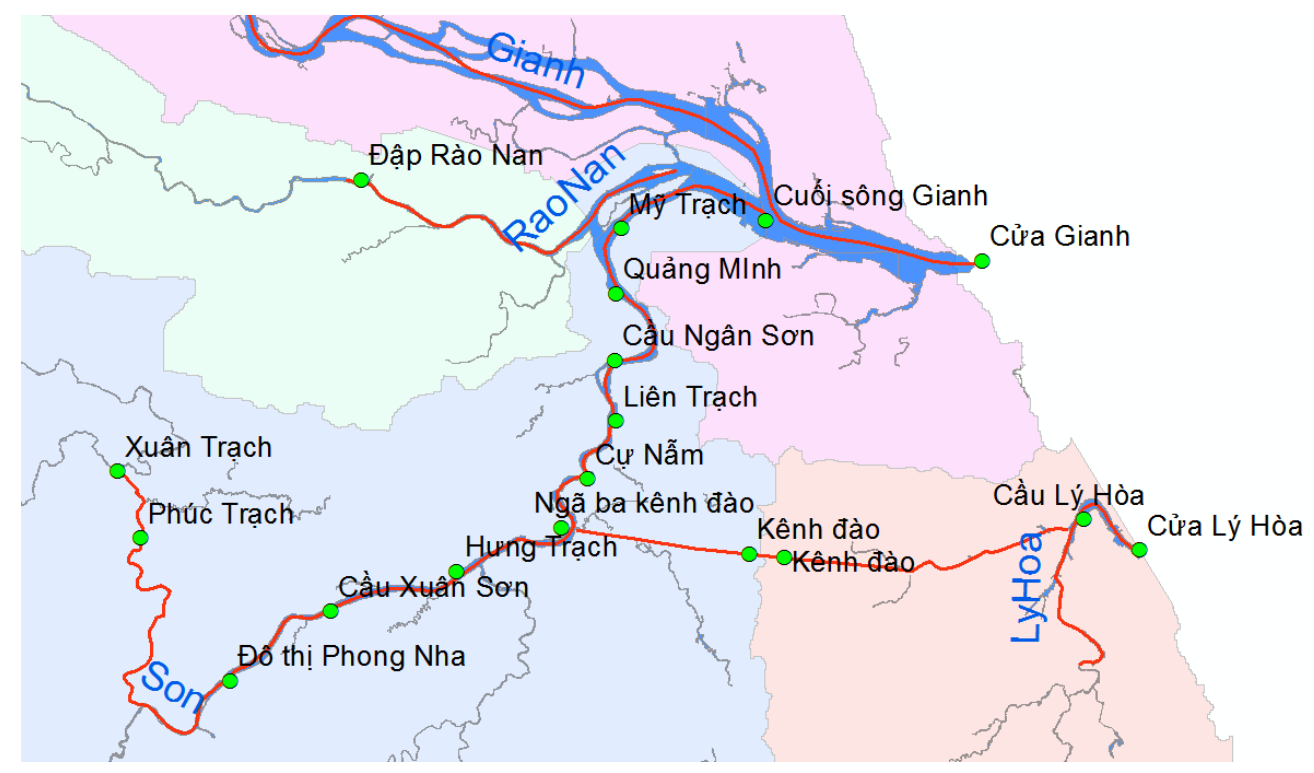

Hình 1. Khu vục hạ lưu sông Sơn - sông Gianh

Tổng lượng mưa trung bình năm khu vực PNKB từ $1.800 \div 2.600 \mathrm{~mm}$, tăng dần từ đồng bằng lên miền núi và từ Bắc vào Nam. Lượng mưa phân bố không đều bởi địa hình hẹp, chia cắt và hướng đón gió mùa khác nhau của tiểu vùng gây nên. Mùa mưa kéo dài từ tháng 8 đến tháng 11 , lượng mưa lớn nhất thường tập trung vào tháng $9,10,11$ chiếm $(56 \div 60) \%$ tổng lượng mưa năm và tháng 10 là tháng có lượng mưa lớn chiếm 43,77\% tổng lượng mưa cả năm. Mùa khô bắt đầu từ tháng 12 đến tháng 7 năm sau. Thời kỳ ít mưa tập trung từ tháng 1 đến tháng 3 chỉ chiếm $5 \% \div 7 \%$ tổng lượng mưa cả năm.

Quy hoạch xây dựng vùng tỉnh Quảng Bình đến năm 2030 được UBND tỉnh Quảng Bình phê duyệt tại QĐ 2865/QĐ-UBND ngày 18/11/2013 và Quy hoạch chung xây dựng vườn Quốc gia PNKB, tỉnh Quảng Bình đến năm 2030 được Thủ tướng Chính Phủ phê duyệt tại quyết định số
QĐ 209/QĐ-TTg ngày 08/02/2015 đã xác định đến năm 2020 dự kiến xây dựng mới khu vực đô thị - du lịch Phong Nha tại trung tâm xã Sơn Trạch theo hướng mô hình đô thị "Xanh" với quy mô tương đương đô thị loại $\mathrm{V}$, nhằm cung cấp các dịch vụ hỗ trợ công tác bảo tồn và phát triển du lịch vườn Quốc gia PNKB. Khu đô thị du lịch Phong Nha với quy mô 1.637ha, trong đó diện tích đất đồi núi, mặt nước khoảng 277ha, thuộc địa phận xã Sơn Trạch, huyện Bố Trạch, tỉnh Quảng Bình (Hình 1) [5].

Khu vực Phong Nha - Kẻ Bàng là thung lũng hẹp bị bao bọc bởi các dãy núi cao, địa hình bị phân cắt mạnh, cao độ không đồng đều và thay đổi lớn tạo ra các vùng cao độ thấp tại các khu vực (Hình 1): - Xã Xuân Trạch và Phúc Trạch, có cao độ từ $8,0 \div 15,0 \mathrm{~m}$; - Xã Sơn Trạch là vùng bán sơn địa có cao độ từ $5,0 \div 12,0 \mathrm{~m}$; - Xã Cự Nẫm và xã Liên Trạch cao từ $2,0 \div 5,0 \mathrm{~m}$ 
(Hình 2). Hàng năm có 1 đến 2 trận lũ gây ngập trên diện rộng. Với các trận lũ lịch sử như lũ 2010, 2016 ngập sâu đến 4m, theo kết quả tính toán hiện trạng, chênh lệch mực nước tại điểm phân thủy hai lưu vực với lũ 2010 là 5,6m và lũ $10 \%$ là $4,5 \mathrm{~m}$.

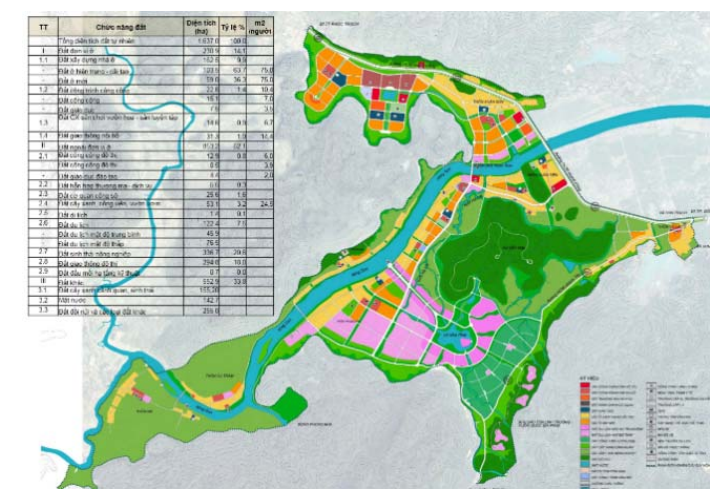

Hình 2. Quy hoạch khu đô thị Phong Nha
Hiện nay, lưu vực sông Son chỉ thoát lũ ra sông Gianh, nằm sát cạnh ở phía Đông có lưu vực sông Lý Hòa, có cao độ thấp với cao độ từ $1,0 \div 4,0 \mathrm{~m}$. Lưu vực sông Son và Lý Hòa có đường phân thủy tại vị trí thấp nhất ở cao trình $8,0 \div$ 10,0m. (Hình 3).

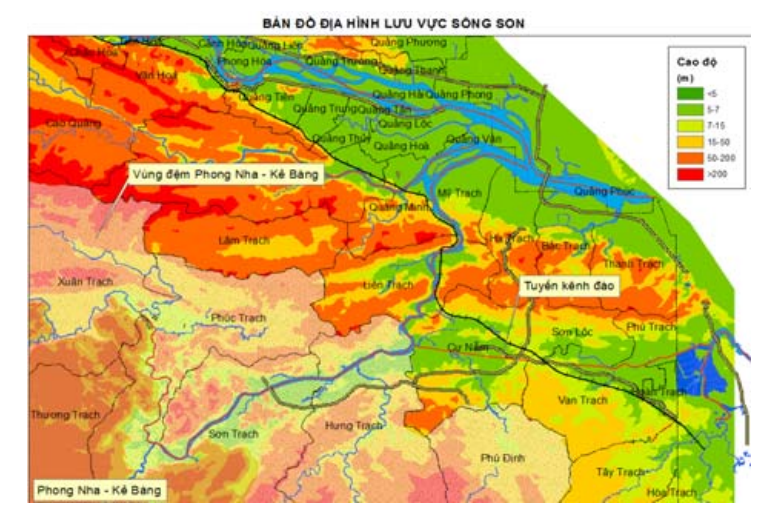

Hình 3. Địa hình hạ lưu sông Son - Lý Hòa

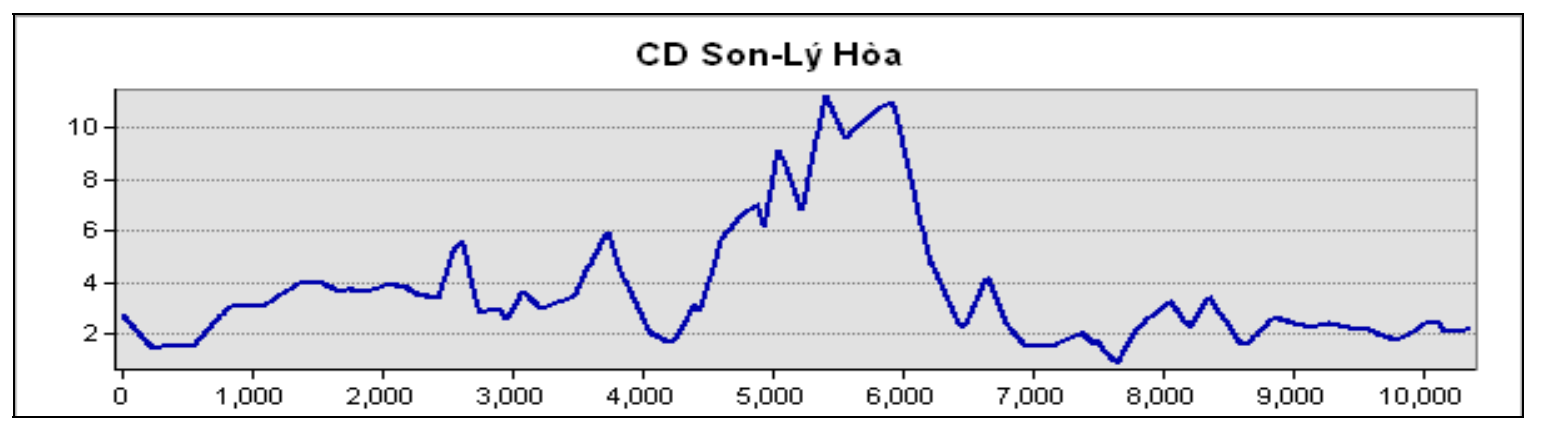

Hình 4. Cắt dọc địa hình tụ nhiên kênh phân lũ

Giải pháp giảm lũ cho sông Son chỉ có thể là phân lũ và nạo vét lòng dẫn chứ không cho phép xây dựng hồ chứa cắt lũ. Thực tế ở nước ta đã có nhiều lưu vực sông mở các đường tắt nối thông ra biển để giảm lũ cho các khu đô thị khi có lũ lớn, như sông Đáy giảm lũ cho Hà Nội, sông Đào Nam Định giảm lũ cho thành Phố Nam Định. Bên cạnh đó là các giải pháp phân lũ vào vùng chậm lũ như lưu vực sông Hồng, sông Hoàng Long [1], phân lũ sang lưu vực khác [2]. Với sông Son, để giảm lũ cho khu vực PNKB giải pháp thoát lũ ngang ra biển bằng đào kênh thông sông Son với sông Lý Hòa là một trong các giải pháp được chú ý, kỳ vọng có hiệu quả.

Bài báo này trình bày giải pháp và hiệu quả thoát lũ ngang ra biển cho lưu vực sông Son, bằng việc phân lũ sang sông Lý Hòa chuyển tắt ra biển. Đây là kết quả nghiên cứu đầu tiên về vấn đề này cho vùng nghiên cứu.

2. Phương pháp nghiên cứu, mô hình thủy lực liên lưu vực sông Son - Lý Hòa

Để mô phỏng, tính toán hiệu quả các phương án phân lũ mô hình MIKE FLOOD được sử dụng. Phạm vi mô phỏng là toàn bộ lưu vực sông Gianh và sông Lý Hòa. Biên trên sông Gianh nằm phía trên trạm thủy văn Đồng Tâm $13,5 \mathrm{~km}$, trên sông Son từ Xuân Trạch, cách cửa động Phong Nha $10 \mathrm{~km}$ về thượng lưu, trên sông Lý Hòa cách thượng lưu cầu Lý Hòa $5 \mathrm{~km}$. Biên dưới là cửa sông Gianh và sông Lý Hòa.

Mô hình MIKE 11 được xây dựng gồm sông Gianh dài $82.650 \mathrm{~m}$; sông Son dài $41.350 \mathrm{~m}$; sông 
Rào Nan dài 11.240m; sông Lý Hòa dài 8.420m và Kênh Đào (tuyến thoát lũ dự kiến) từ sông Son sang Sông Lý Hòa dài 14.740m (Hình 5). Mặt cắt sông tính toán được thu thập và đo mới bổ sung các năm 2014 và 2018 , hoặc trích từ bản đồ DEM, gồm: sông Gianh có 74; sông Son với 57 mặt cắt; sông Lý Hòa có 13 mặt cắt; sông Rào Nan có 10 mặt cắt; Kênh Đào mới 05 mặt cắt. Các cầu trên dòng chính được đưa vào mô phỏng trên mô hình MIKE 11 gồm cầu Chợ Gát, Minh Cầm, Châu Hóa, Văn Hóa, Quảng Hải, Gianh trên sông Gianh; Ngân Sơn (cầu đường sắt) và Xuân Sơn trên sông Son; đập dâng Rào Nan trên sông Rào Nan, cầu Lý Hòa trên sông Lý Hòa. Ngoài ra trên nhánh kênh nối sông Son và Lý Hòa có bố trí công trình điều tiết dạng đập nhằm khống chế sự trao đổi nước cho các phương án khác nhau trong tính toán. Biên trên của mô hình là các biên đóng, biên dưới là mực nước tại cửa sông Gianh và cửa Lý Hòa được áp mực nước triều tại Tân Mỹ. Biên lưu lượng gia nhập khu giữa được tính từ mô hình MIKE NAM và chia thành 80 điểm nhập lưu theo các tiểu lưu vực.

Mô hình 2 chiều mô phỏng vùng đồng bằng ngập lũ được xây dụng bằng mô hình MIKE 21FM. Vùng 2 chiều tính toán trên sông Gianh được mô phỏng từ phía trước trạm thủy văn Mai Hóa, trên sông Son từ Xuân Trạch và toàn bộ lưu vực sông Lý Hòa. Lưới tính toán được chia theo

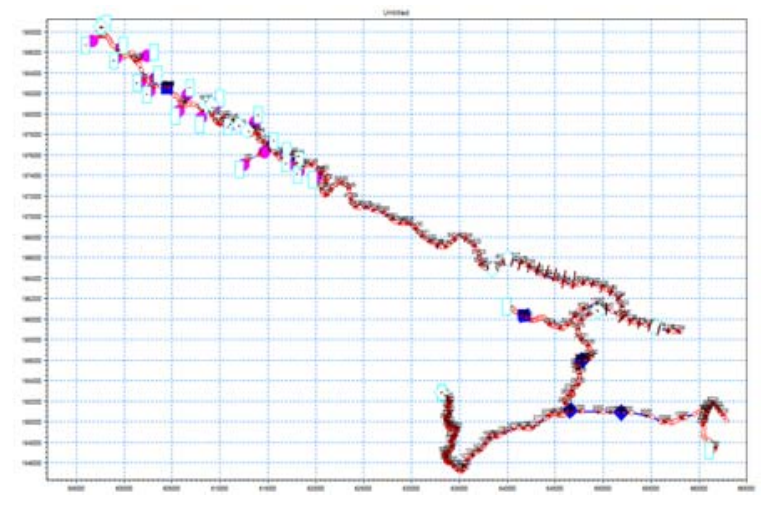

Hình 5. Mạng sông tính toán nguyên tắc mịn ở các khu vực có địa hình biến đổi mạnh và ven sông, thưa ở các vùng bằng phẳng. Toàn miền tính toán có 69.750 phần tử với 26.352 điểm nút (Hình 6), lưới địa hình tính toán được nội suy từ dữ liệu bản đồ tỉ lệ 1:10 000. Trên mô hình 2 chiều, các công trình dạng tuyến có cản nước được mô phỏng là đê (DIKE) bao gồm các tuyến đường: tỉnh lộ 659 , tỉnh lộ $12 \mathrm{~A}$, quốc lộ $1 \mathrm{~A}$; đường sắt, đường Hồ Chí Minh. Bước thời gian tính toán của mô hình 2 chiều lớn nhất là 1,5 giây; Hệ số nhám toàn vùng lấy trung bình $\mathrm{n}=0,33$.

Mô hình MIKE 11 và MIKE 21FM được kết nối để trao đổi nước với nhau qua các liên kết bên là đê của các nhánh sông được mô phỏng trong MIKE 11, gồm 13 kết nối bên.

Mô hình MIKE Flood được hiệu chỉnh với lũ thực tế 2016 và kiểm định với lũ 2010 bằng mực nước, lưu lượng tại các trạm thủy văn và vết lũ năm 2010. Kết quả kiểm định và hiệu chỉnh quá trình mực nước và lưu lượng thể hiện trên Hình 7. Kết quả kiểm định cho thấy mô hình xây dựng đã mô phỏng được quá trình lũ, đường mực nước lớn nhất, phù hợp với số liệu thực đo. Hệ số NASH khi kiểm định và hiệu chỉnh tại trạm Đồng Tâm, Mai Hóa và Quảng Minh đều lớn hơn 0,75 , chênh lệch mực nước tại các điểm vết lũ lớn nhất là $0,30 \mathrm{~m}$. Tại khu vực Phong Nha sai số dưới $0,07 \mathrm{~m}$.

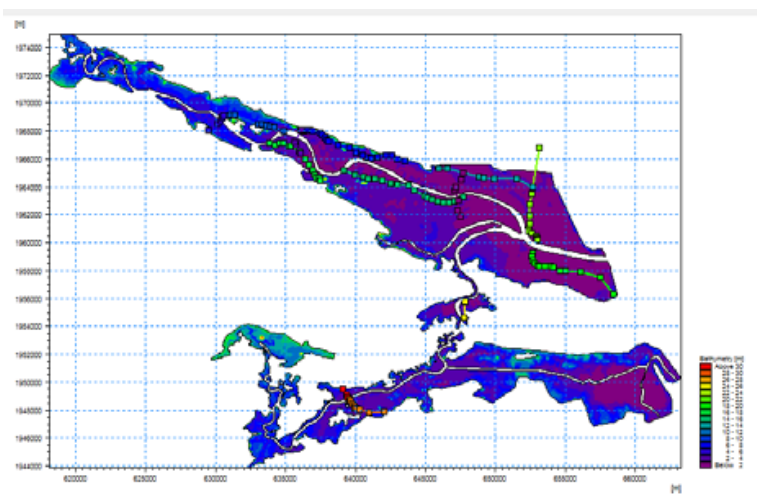

Hìn 6. Lưới mô phỏng vùng dụ án 


\section{BÀI BÁO KHOA HỌC}

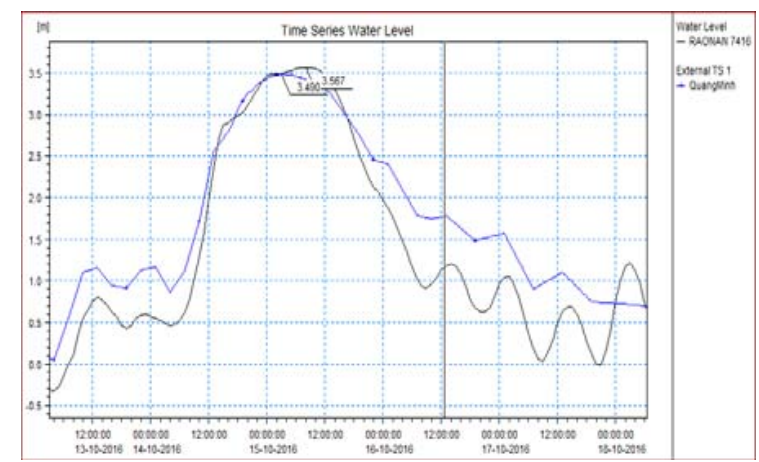

Quảng Minh lũ 2016

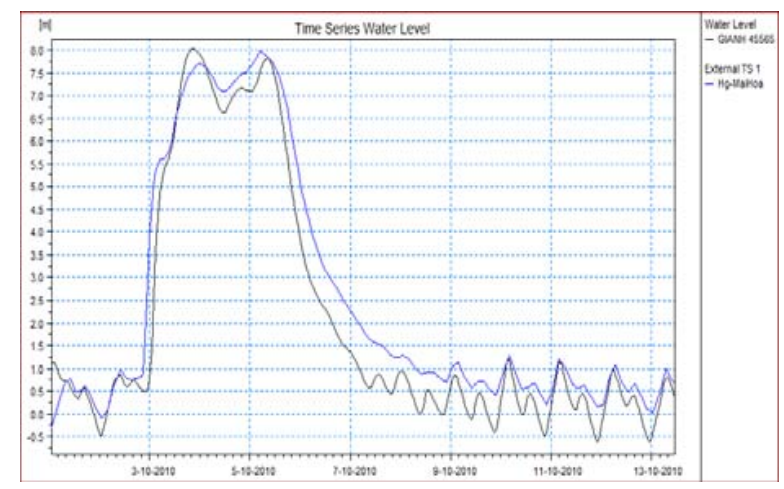

Mai Hóa lũ 2010

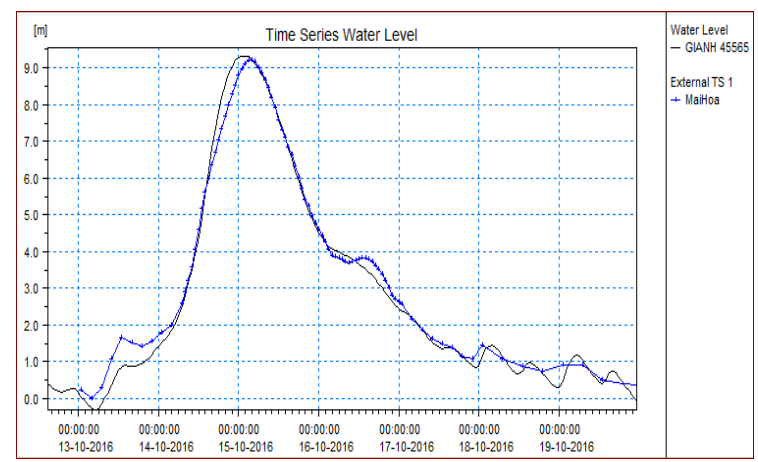

Mai Hóa lũ 2016

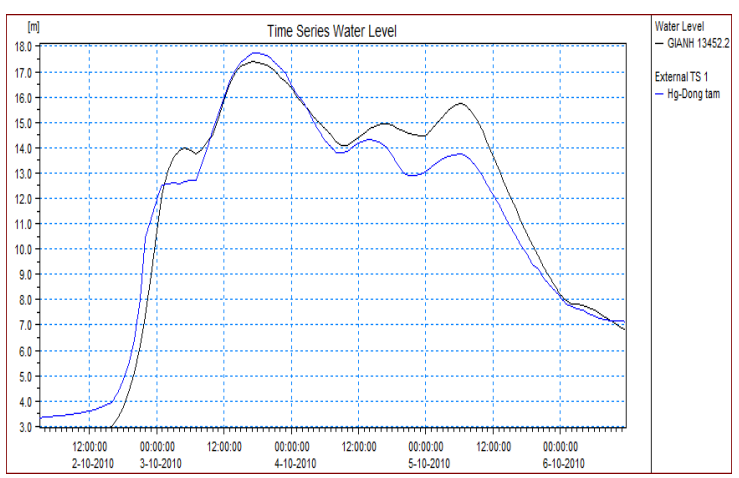

Đồng Tâm lũ 2010

Hình 7. Kết quả hiệu chỉnh mô hình (2016) kiểm định mô hình (2010)

\section{Kết quả tính hiện trạng ngập lụt}

Lũ tháng 10/2010 xảy ra từ ngày 2-6 tháng 10, đỉnh lũ ở Đồng Tâm trên sông Gianh vào ngày $04 / 10$ và trên sông Son là ngày $05 / 10 / 2010$. Trận lũ này có lượng mưa lớn nhất đã xảy ra trên sông Son. Mưa 3 ngày lớn nhất ở trạm Troóc là $1001 \mathrm{~mm}$, ở trạm Việt Trung là $879 \mathrm{~mm}$, đặc biệt ở Minh Hóa là $1442 \mathrm{~mm}$, mưa lớn nhất trong 24 giờ là $798 \mathrm{~mm}$. Tổng lượng mưa 03 ngày tại Việt Trung và Troóc có tần suất nhỏ hơn $0,5 \%$, ở Minh Hóa là $0,2 \%$.

Tương ứng với đặc điểm địa hình, kết quả

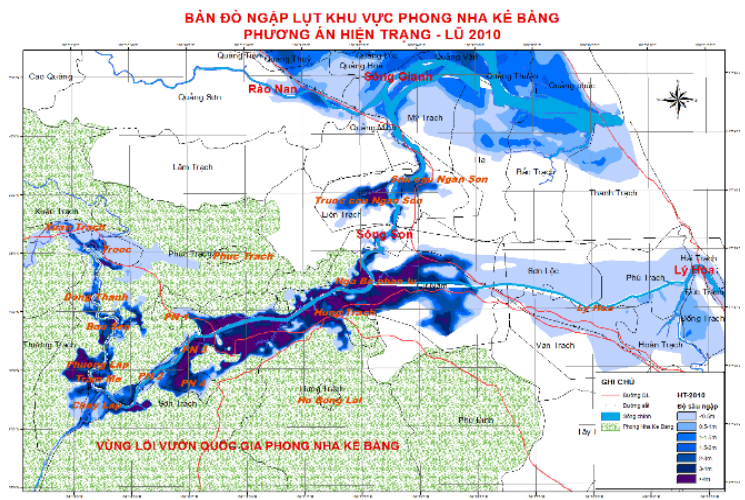

Lũ thực tế 2010 tính toán thể hiện trên Hình 8 , cho thấy, trên dòng chính sông Son có 03 vị trí có chênh lệch mực nước lớn đó là: + Tại cầu đường sắt, chênh lệch mực nước là $0,45 \mathrm{~m}$ với lũ 2010; Trên đoạn sông từ Cự Nẫm đến Mỹ Trạch, với chiều dài $6 \mathrm{~km}$, dòng chảy có độ dốc $0,04 \%$, chênh lệch mực nước đến 2,52m; + Chênh lệch mực nước giữa sông Son và sông Lý Hòa với lũ 2010 là $5,6 \mathrm{~m}$, cao độ dòng chảy ở phía sông Son là $8,1 \mathrm{~m}$, phía sông Lý Hòa là 2,5m. Với lũ $10 \%$ chênh lệch là $4,5 \mathrm{~m}$, cao độ mực nước phía sông Son là $6,0 \mathrm{~m}$, phía sông Lý Hòa là $1,5 \mathrm{~m}$.

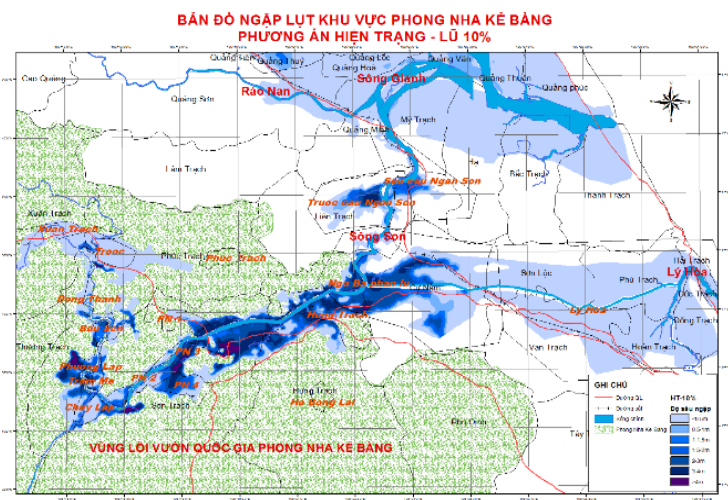

Lũ thiết kế $10 \%$

Hình 8. Bản đồ ngập lụt với địa hình hiện trạng, lũ thiết kế $10 \%$ 
Hiện trạng khu đô thị Phong Nha có độ ngập sâu lớn nhất lên đến hơn 3,5m. Diện tích ngập và chiều sâu ngập các kịch bản lũ cụ thể:

+ Với lũ 10\%, diện tích ngập lụt là 398ha. Vùng ngập sâu từ $2,5 \mathrm{~m}$ trở lên chiếm đến $48 \%$ diện tích vùng ngập với diện tích 193ha. Mực nước lớn nhất trung bình khu vực là $6,76 \mathrm{~m}$;

+ Với lũ 5\% diện tích ngập là 468ha; vùng ngập sâu từ $2,5 \mathrm{~m}$ trở lên chiếm đến $72 \%$ diện tích vùng ngập với diện tích 341ha; Mực nước lớn nhất trung bình khu vực là $7,44 \mathrm{~m}$;

+ Với lũ $2 \%$ diện tích ngập là 542 ha; vùng ngập sâu từ $2,5 \mathrm{~m}$ trở lên chiếm đến $85 \%$ diện tích vùng ngập với diện tích 448ha; Mực nước lớn nhất trung bình khu vực là $8,95 \mathrm{~m}$;

+ Với lũ lịch sử 2010 (với tần suất lớn hơn $2 \%$ ) diện tích ngập là 526ha; vùng ngập sâu từ $2,5 \mathrm{~m}$ trở lên chiếm đến $88 \%$ diện tích vùng ngập với diện tích 464ha; Mực nước lớn nhất trung bình khu vực là 9,44m;

+ Với lũ lịch sử 2016 diện tích ngập là 542ha; vùng ngập sâu từ $2,5 \mathrm{~m}$ trở lên chiếm đến $90 \%$ diện tích vùng ngập với diện tích 493ha; Mực nước lớn nhất trung bình khu vực là $9,87 \mathrm{~m}$;

Như vậy, khu vực đô thị Phong Nha có mức độ ngập sâu trên diện rộng. Với lòng dẫn hiện trạng, khi xây dựng đô thị với cao độ san nền dự kiến với lớn hơn $5 \mathrm{~m}$ thì với lũ $10 \%$ vẫn có thể ngập sâu đến $2 \mathrm{~m}$, và đến $3 \mathrm{~m}$ với lũ $2 \%$, với lũ lịch sử 2010 và 2016 là hơn $5 \mathrm{~m}$.

\section{Giải pháp thoát lũ ngang ra biển và hiệu quả}

4.1. Các giải pháp thoát lũ được nghiên cứu

Trên cơ sở kết quả điều tra thực tế tình hình ngập lụt, kết quả khảo sát địa hình lòng dẫn tuyến sông Son, nền địa hình hệ thống các bản đồ của khu vực, 03 nhóm phương án chính đã được xem xét tính toán: Nhóm 1: Tăng khả năng thoát lũ trên sông Son bằng giải pháp mở rộng sông Son, các cầu trên sông Son gồm Ngân Sơn, Xuân Sơn có các phương án 2, 3, 4; Nhóm 2: Phân lũ sang Lý Hòa bằng giải pháp đào kênh phân lũ qua sông Lý Hòa (nối sông Son với sông Lý Hòa), bao gồm cả các giải pháp lên đê, nạo vét sông Lý Hòa có phương án 1, 5, 6; Nhóm 3:
Kết hợp hai nhóm giải pháp trên gồm phương án 7 và 8 . Các phương án được tính toán với lũ thực tế năm 2010, 2016, và mưa với tần suất $2 \%, 5 \%$ và $10 \%$, mực nước tại cửa biển được tính cho 02 trường hợp là: triều với tần suất $10 \%$ và triều thực tế năm 2010 (triều cường). Bài báo trình bày cụ thể kết quả tính toán nhóm phương án 2 bằng giải pháp phân lũ ngang ra biển qua lưu vực sông Lý Hòa, chi tiết các phương án như sau:

- PA1: Các phương án thoát lũ sang cửa Lý Hòa: + Địa hình sông Son như hiện trạng; + Đào kênh phân lũ sang sông Lý Hòa với chiều dài $\mathrm{L}=14,720 \mathrm{~m}$, chiều rộng đáy sông $\mathrm{B}=100 \mathrm{~m}$, cao độ đáy kênh tại đầu kênh đào $-1,0 \mathrm{~m}$, cao độ đáy kênh ở cuối sông tại vị trí cầu Lý Hòa -2,0m, độ dốc kênh i $=7$ x $10^{-5}$.

- PA6: Phân lũ kết hợp nạo vét sông Lý Hòa. Địa hình như phương án $1\left(\mathrm{~B}=100 \mathrm{~m} ; \mathrm{Z}_{\mathrm{dk}}=\right.$ $\left.1,0 \mathrm{~m}, \mathrm{i}=7 \times 10^{-5}\right)$ kết hợp nạo vét sông Lý Hòa với cao độ đáy sông tại cầu Lý Hòa $Z_{\mathrm{ds}}=-2 \mathrm{~m}$ và tôn cao đê ngăn lũ tràn $10 \%$. Cao trình đỉnh đê Lý Hòa từ $+3,0 \div+3,1 \mathrm{~m}$.

\subsection{Tính toán xác định qui mô kênh đào (PA1)}

Để tính toán xác định quy mô kênh đào, phương án phân lũ sang Lý Hòa (Phương án 1) bằng kênh thông, nối sông Son và sông Lý Hòa được tính cho 05 kịch bao gồm: cao độ đáy, độ dốc đáy và chiều rộng đáy sông. Trong các phương án này hệ số mái bờ sông được tính toán với $m=1$. Các cao trình đáy kênh xem xét gồm: $-1,0 \mathrm{~m},-2,0 \mathrm{~m}$ và $-3,0 \mathrm{~m}$, với chiều rộng đáy kênh là $\mathrm{B}=100 \mathrm{~m}$; các phương án chiều rộng đáy kênh gồm $\mathrm{B}=100 \mathrm{~m}, \mathrm{~B}=70 \mathrm{~m}, \mathrm{~B}=50 \mathrm{~m}$ xét với $\mathrm{Z}_{\mathrm{dk}}=$ $-2,0 \mathrm{~m}$ tính với mưa và triều $10 \%$. Kết quả tính cho thấy:

- Về diện tích ngập lụt: Khi đào kênh phân lũ, khu vực Hưng Trạch giảm ngập lụt nhiều nhất đến $90 \%$ diện tích với độ ngập sâu 2,5m; khu vực đô thị Phong Nha chỉ giảm được $25 \%$ diện tích ngập lụt, nhưng với độ sâu lớn hơn 2,0m thì giảm được $50 \%$ và không còn độ sâu ngập trên $3,5 \mathrm{~m}$. Khu vực hạ lưu sông Lý Hòa do đê thấp và bị phân lũ sang làm diện tích ngập lụt tăng cao từ 200ha lên 1700ha với độ sâu lên đến 2,0m. 
- Về mực nước trên dòng chính sông Son: Các phương án phân lũ làm giảm mực nước tại cửa động Phong Nha đến thượng lưu cầu Xuân Sơn là $0,65 \mathrm{~m}$ (với $\mathrm{P}=10 \%$ ). Từ Hưng Trạch về hạ lưu sông Son giảm được $1,0 \mathrm{~m}$ và lớn nhất tại đầu Kênh Đào là $1,5 \mathrm{~m}$. Từ ngã ba Kênh Đào về hạ lưu sông Son sự thay đổi mực nước giảm dần, tại cuối sông Son mực nước chỉ thay đổi $0,2 \mathrm{~m}$.

- Lưu lượng và tổng lượng lũ thoát qua Kênh
Đào lớn nhất là $1597 \mathrm{~m}^{3} / \mathrm{s}$ và 145 triệu $\mathrm{m}^{3}$.

Các trường hợp thay đổi quy mô Kênh Đào cho thấy sự sai khác mực nước và lưu lượng là không đáng kể (Bảng 1). Bề rộng đáy kênh lớn nhất $100 \mathrm{~m}$, phù hợp với chiều rộng đáy sông Lý Hòa.

Qua tính toán, lựa chọn phương án kênh có B $=100 \mathrm{~m}$, cao độ đầu kênh $\mathrm{Z}_{\mathbb{đ} \mathrm{k}}=-1,0 \mathrm{~m}$ để tính toán, so sánh trong các trường hợp tiếp theo.

Bảng 1. Kết quả tính toán các phuoong án thoát lũ sang Lý Hòa mura và triều 10\%

\begin{tabular}{|c|c|c|c|c|c|c|c|}
\hline \multirow{2}{*}{ TT } & \multirow{2}{*}{ Vị trí } & \multirow{2}{*}{$\begin{array}{c}\text { HT } \\
\text { (PA0) }\end{array}$} & \multicolumn{3}{|c|}{$\mathrm{B}=100 \mathrm{~m}$} & \multicolumn{2}{|c|}{$\mathrm{Z}_{\mathrm{dk}}=-2 \mathrm{~m}$} \\
\hline & & & $Z=-1 \mathrm{~m}$ & $Z=-2 m$ & $Z=-3 m$ & $\mathrm{~B}=70 \mathrm{~m}$ & $\mathrm{~B}=50 \mathrm{~m}$ \\
\hline I & Mực nước (m) & & & & & & \\
\hline 1 & Trung tâm đô thị Phong Nha & 6,76 & 6,27 & 6,27 & 6,27 & 6,28 & 6,3 \\
\hline 2 & Cầu Xuân Sơn & 6,61 & 6,05 & 6,05 & 6,04 & 6,06 & 6,08 \\
\hline 3 & Ngã ba Kênh Đào & 5,9 & 4,49 & 4,43 & 4,4 & 4,55 & 4,71 \\
\hline 4 & TL cầu Ngân Sơn & 4,39 & 3,41 & 3,37 & 3,34 & 3,46 & 3,56 \\
\hline 5 & Cuối sông Son & 1,6 & 1,4 & 1,39 & 1,39 & 1,4 & 1,42 \\
\hline 6 & Đầu Kênh Đào phía sông Son & 5,9 & 4,13 & 4 & 3,93 & 4,24 & 4,52 \\
\hline 7 & Cuối Kênh Đào phía Lý Hòa & 1,74 & 3,7 & 3,76 & 3,79 & 3,63 & 3,44 \\
\hline 8 & Cầu Lý Hòa & 1,62 & 2,54 & 2,58 & 2,61 & 2,51 & 2,4 \\
\hline II & Lưu lượng (m³/s) & & & & & & \\
\hline 1 & Cầu Xuân Sơn & 5013 & 4519 & 4521 & 4522 & 4516 & 4511 \\
\hline 2 & Kênh Đào & 0 & 1476 & 1556 & 1597 & 1390 & 1149 \\
\hline 3 & Cầu Lý Hòa & 721 & 1584 & 1653 & 1691 & 1546 & 1434 \\
\hline 4 & Cầu Ngân Sơn & 5561 & 3942 & 3873 & 3835 & 4002 & 4182 \\
\hline III & Tổng lượng qua kênh đào $\left(10^{6} \mathrm{~m}^{3}\right)$ & 0 & 138 & 143 & 145 & 135 & 122 \\
\hline
\end{tabular}

4.3. Phưong án đào kênh thông sông Son sông Lý Hòa kết hợp nạo vét và tôn cao đê sông Lý Hòa (PA6)

Trên cơ sở Phương án 1 (lựa chọn $\mathrm{B}=100 \mathrm{~m}$, $\left.\mathrm{Z}_{\mathrm{đk}}=-1,0 \mathrm{~m}\right)$, tính toán phương án phân lũ kết hợp nạo vét và tôn cao đê sông Lý Hòa cho kết quả tại Bảng 2:

Diện tích ngập lụt và độ ngập sâu tại khu vực Hưng Trạch (hạ lưu cầu Xuân Sơn đến ngã 3 Kênh Đào) các phương án trong nhóm không có sự thay đổi nhiều, chỉ thay đổi so với hiện trạng.

Giải pháp giảm lũ cho sông Son có hiệu quả tương đối với địa hình hiện trạng, với lũ 2016 tại khu vực Phong Nha về mực nước giảm 2,25m, thời gian ngập lụt giảm còn $1 / 2$ so với hiện trạng. Khi san nền hoàn chỉnh quy hoạch với cao độ lớn hơn 5m, mức độ giảm ngập lụt cho vùng nghiên cứu là rất lớn. Xét lâu dài giải pháp thoát lũ này có hiệu quả rất lớn và có tính khả thi.

+ Về mực nước (hay độ ngập sâu) giảm trung bình trên toàn đô thị là: $0,50 \mathrm{~m}$ (lũ $10 \%) ; 0,98 \mathrm{~m}$ (lũ 5\%); 1,52m (lũ 2\%); 1,40m (lũ năm 2010) và 1,70m (lũ năm 2016).

+ Về diện tích ngập lụt: Tổng diện tích ngập lụt ứng với lũ $10 \%, 5 \%, 2 \%, 2010,2016$ giảm lần lượt là: 58 ha $(8 \%), 51,5$ ha $(11,6 \%), 58,2$ ha $(11,2 \%), 27,2$ ha $(5 \%)$, 44ha (8,2\%); Diện tích ngập lụt với độ sâu ngập trên $2,5 \mathrm{~m}$ giảm tương ứng là 7,0 ha $(4,4 \%), 93,5$ ha $(27,5 \%), 108$ ha (24\%), 73ha (15,6\%), 105ha (21,5\%).

+ Về thời gian ngập lụt với độ sâu $1 \mathrm{~m}$ giảm khoảng $10 \%$, từ 33 giờ còn 31,5 giờ (lũ $10 \%$ ), 
38,4 giờ còn 34,5 giờ (1ũ 5\%), 42,6 giờ còn 28,2 giờ (lũ 2\%), 64,4 giờ còn 22,5 giờ (lũ năm 2016).

Với độ sâu đến $2 \mathrm{~m}$ thì thời gian ngập giảm khoảng $20 \%$ đến $40 \%$, từ 33 giờ còn 31,5 giờ (lũ $10 \%), 38,4$ giờ còn 34,5 giờ (lũ $5 \%$ ), 42,6 giờ còn 28,2 giờ (lũ 2\%), 64,4 giờ còn 19,2 giờ (lũ năm 2016).

+ Với cao trình san nền xây dựng theo quy hoạch khu đô thị Phong Nha với cao trình $+5 \div$ +7,0m thì chỉ ngập dưới $1 \mathrm{~m}$ (lũ 10\%).

Về hiệu quả phân giảm lũ sang sông Lý Hòa có thể tương đương với giải pháp giảm lũ bằng hồ chứa có dung tích đến 260 triệu $\mathrm{m}^{3}$ (với lũ
$2 \%$ ) cho toàn lưu vực sông Son. Ngoài việc giảm ngập lụt tại khu đô thị Phong Nha, còn làm giảm lũ cho hạ lưu sông Gianh, lưu lượng đỉnh lũ trên sông Son từ sau Kênh Đào về hạ lưu giảm $2000 \mathrm{~m}^{3} / \mathrm{s}$, giảm mực nước từ 0,5 -:- 1,3m tại Mỹ Trạch.

Bên cạnh việc giảm ngập lụt cho khu đô thị Phong Nha thì cũng làm giảm lũ đáng kể ở hạ lưu sông Son phía sau Kênh Đào và làm gia tăng ngập lụt cho lưu vực sông Lý Hòa với lũ lớn hơn $10 \%$ về diện và thời gian ngập lụt lên gần gấp 2 lần.

Bảng 2. Tổng hợp các thông số thưy lực, ngập lụt các phưong án tính toán

\begin{tabular}{|c|c|c|c|c|c|c|c|c|}
\hline \multirow[t]{2}{*}{ Kết quả tính toán } & \multicolumn{2}{|c|}{$10 \%$} & \multicolumn{2}{|c|}{$5 \%$} & \multicolumn{2}{|c|}{2010} & \multicolumn{2}{|c|}{2016} \\
\hline & HT & PA6 & HT & PA6 & HT & PA6 & HT & PA6 \\
\hline \multicolumn{9}{|l|}{ 1. Khu vục đô thị Phong Nha } \\
\hline Cao trình ngập lụt lớn nhất (m) & 6,76 & 6,27 & 7,44 & 7,41 & 9,44 & 8,04 & 9,87 & 7,98 \\
\hline Chiều sâu ngập (h) lớn nhất (m) & 4,19 & 3,84 & 6,63 & 4,44 & 7,81 & 5,84 & 7,87 & 7,43 \\
\hline Thời gian ngập với h = 1m (giờ) & 33,3 & 31,5 & 38,4 & 34,5 & & & 64,8 & 63,9 \\
\hline Thời gian ngập với $\mathrm{h}=2 \mathrm{~m}$ (giờ) & 14,1 & 8,7 & 20,4 & 14,1 & & & 26,7 & 19,2 \\
\hline Diện tích ngập lụt $\mathrm{S}$ (ha) toàn bộ & 398 & 369 & 445 & 394 & 526 & 499 & 542 & 498 \\
\hline $\mathrm{S}$ ứng với $\mathrm{h} \geq 1,0 \mathrm{~m}$ & 346 & 340 & 445 & 394 & 516 & 484 & 536 & 480 \\
\hline $\mathrm{S}$ ứng với $\mathrm{h} \geq 2,0 \mathrm{~m}$ & 212 & 196 & 373 & 328 & 489 & 431 & 514 & 424 \\
\hline $\mathrm{S}$ ứng với $\mathrm{h} \geq 2,5 \mathrm{~m}$ & 162 & 154 & 341 & 247 & 464 & 391 & 493 & 387 \\
\hline $\mathrm{S}$ ứng với $\mathrm{h} \geq 3,0 \mathrm{~m}$ & 131 & 124 & 300 & 178 & 434 & 361 & 466 & 356 \\
\hline \multicolumn{9}{|l|}{ 2. Khu vục sông Lý Hoà } \\
\hline Cao trình ngập lụt lớn nhất (m) & 1,62 & 2,13 & 1,69 & 2,62 & 2,22 & 2,94 & 2,14 & 3,05 \\
\hline Chiều sâu ngập (h) lớn nhất (m) & 0,72 & 0,72 & 1,04 & 2,64 & 1,57 & 3,26 & 1,57 & 3,30 \\
\hline Thời gian ngập với $\mathrm{h}=0,5 \mathrm{~m}$ (giờ) & 0,0 & 0,0 & 0,0 & 25,2 & 12,6 & 30,0 & 61,8 & 58,2 \\
\hline Diện tích ngập lụt (ha) & 190 & 115 & 688 & 1271 & 1072 & 1907 & 1070 & 1982 \\
\hline $\mathrm{S}$ ứng với $\mathrm{h} \geq 1,0 \mathrm{~m}$ & 8 & 12 & 250 & 952 & 951 & 1801 & 951 & 1840 \\
\hline $\mathrm{S}$ ứng với $\mathrm{h} \geq 2,0 \mathrm{~m}$ & & & & 203 & 43 & 1515 & 43 & 1567 \\
\hline Tổng lượng qua kênh đào $\left(10^{6} \mathrm{~m}^{3}\right)$ & & 156,3 & & 271,7 & & 321,8 & & 262,5 \\
\hline Đỉnh lũ qua kênh đào $\left(\mathrm{m}^{3}\right)$ & & 1414 & & 2662 & & 3279 & & 3261 \\
\hline
\end{tabular}

\section{Kết luận và kiến nghị}

Giải pháp phân lũ ngang ra biển bằng việc đào kênh thông sông Son và sông Lý Hòa đã được tính toán và khẳng định có hiệu quả nhất định trong việc giảm ngập lụt cho khu vực $\mathrm{PNKB}$, và hạ lưu sông Son, nhưng cũng làm gia tăng ngập lụt cho lưu vực sông Lý Hòa với lũ lớn.

Qua tính toán thủy lực liên lưu vực đã xác định được quy mô giải pháp phân lũ sang sông Lý Hòa với chiều dài $\mathrm{L}=14.720 \mathrm{~m}$, chiều rộng đáy sông $\mathrm{B}=100 \mathrm{~m}$, cao độ đáy kênh tại đầu kênh đào $-1,0 \mathrm{~m}$, cao độ đáy kênh ở cuối sông tại cầu Lý Hòa -2,0m, độ dốc kênh i $=7$ x 10-5. Bên cạnh đó để nâng cao năng lực thoát lũ cần kết hợp nạo vét sông Lý Hòa với chiều rộng đáy là $100 \mathrm{~m}$, cao độ đáy là $-2,0 \mathrm{~m}$. Để ngăn lũ tràn do phân lũ từ sông Son sang sông Lý Hòa cần thiết 


\section{BÀI BÁO KHOA HỌC}

tôn cao đê sông Lý Hòa để chống lũ với tần suất 10\%, hoặc cao hơn.

Hiệu quả giảm lũ của giải pháp phân lũ qua sông Lý Hòa là giảm chiều sâu ngập lụt tại khu vực Phong Nha $0,65 \div 1,30 \mathrm{~m}$, giảm diện tích ngập lụt $5 \% \div 30 \%$, giảm thời gian ngập lụt từ 10 $\div 40 \%$. Với cao trình san nền xây dựng theo quy hoạch khu đô thị Phong Nha thì với lũ 10\% chỉ ngập dưới 1m. Giải pháp phân lũ sang sông Lý Hòa có thể tương đương với giải pháp giảm lũ bằng hồ chứa có dung tích đến 260 triệu $\mathrm{m}^{3}$ (với lũ $2 \%$ ) cho toàn lưu vực sông Son. Ngoài việc giảm ngập lụt tại khu đô thị Phong Nha, nó còn làm giảm lũ cho vùng hạ lưu sông Gianh. Khi phân lũ sang Lý Hòa làm lưu lượng đỉnh lũ trên sông Son từ sau Kênh Đào về hạ lưu giảm $2000 \mathrm{~m}^{3} / \mathrm{s}$, giảm mực nước từ $0,5 \div 1,3 \mathrm{~m}$ tại Mỹ Trạch.

Kết quả tính toán cho thấy giải pháp đề xuất có hiệu quả về mặt thủy lực, nhưng cần được nghiên cứu chi tiết, hoàn chỉnh với những đánh giá tác động đến lưu vực sông Lý Hòa, sự ổn định, biến động của hai cửa biển.

\section{Tài liệu tham khảo}

1. Hà Văn Khối (2011), Báo cáo đề tài độc lập cấp nhà nước "Nghiên cưu co sở khoa học cho việc xóa khu chậm lũ sông Hồng, sông Đáy, sông Hoàng Long”.

2. Lê Văn Nghị và nnk, (2019), Giải pháp chỉnh trị ổn định lòng dẫn khu vực hợp lưu khi chuyển lũ luu vưc, áp dụng cho hợp lư Khe Trí - Ngàn Trươi, tạp chí khoa học thủy lợi và môi trường, số 65.

3. Lê Văn Nghị và nnk, (2017), Báo cáo điều tra, khảo sát, nghiên cưu giải pháp thoát lũ, giảm ngập khu vực Phong Nha - Kẻ Bàng, Phòng thí nghiệm trọng điểm quốc gia về động lực học sông biển.

4. Viện Quy hoạch Đô thị - Nông thôn Quốc gia (2015), Quy hoạch tổng thể phát triển khu du lịch Quốc gia Phong Nha - Kẻ Bảng, tỉnh Quảng Bình đến năm 2030;

5. Viện Quy hoạch Đô thị - Nông thôn Quốc gia (2017), Quy hoạch phân khu - đô thị du lịch Phong Nha, tỷ lệ $1 / 2000$.

6. Viện Quy hoạch Thủy lợi (2010), Rà soát, cập nhật, bổ sung quy hoạch phát triển và bảo vệ nguồn nước, Gianh \& phu cận.

\section{PROPOSING SOLUTIONS TO REDUCE FLOODING IN PHONG NHA - KE BANG BY THE CANAL CONNECTING SON AND LY HOA RIVERS}

\section{Le Van Nghi ${ }^{1}$ \\ ${ }^{1}$ Vietnam academy for water resources}

Abstract: Phong Nha - Ke Bang national park has been recognized as a world natural heritage. This is a famous tourist destination which is planned to develop into an urban area. This area is often inundated by floods from Son river. The flow direction of Son river is parallel to the coast but it is separated from the sea by the Ly Hoa river watershed. This paper presents a flood reduction solution for the PNKB area by horizontal flood diversion through the opening of a channel connecting Son and Ly Hoa rivers. The channel has a length of $14.70 \mathrm{~km}$, a bottom width of $100 \mathrm{~m}$, a bottom slope $i=7 \times 10^{-5}$, the bottom elevation at the end of channel is $-2.0 \mathrm{~m}$. The solution reduces the water level in the study area from $0.5 \div 1.5 \mathrm{~m}$, reducing the flooded area by $25 \%$, and reducing the flood time by $40 \%$ with recent history events.

Keywords: PNKB, Flood solution, Gianh river, Horizontal flood diversion. 